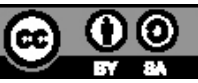

DOI: https://doi.org/10.4312/keria.20.3.95-108

\title{
Alenka Jensterle-Doležal
}

\section{In the Realm of Politics, Nonsense, and the Absurd: The Myth of Antigone in West and South Slavic Drama in the Mid-Twentieth Century}

Throughout history humans have always felt the need to create myths and legends to explain and interpret human existence. One of the classical mythical figures is ancient Antigone in her torment over whether to obey human or divine law. This myth is one of the most influential myths in European literary history. In the creation of literature based on this myth there have always been different methods and styles of interpretation. Literary scholars always emphasised its philosophical and anthropological dimensions. ${ }^{1}$ The first variants of the myth of Antigone are of ancient origin: the play Antigone by Sophocles (written around $441 \mathrm{BC}$ ) was a model for others throughout cultural and literary history. ${ }^{2}$ There are various approaches to the play, but the well-established central theme deals with one question: the heroine Antigone is deeply convinced that she has the right to reject society's infringement on her freedom and to act, to recognise her familial duty, and not to leave her brother's body unburied on the battlefield. She has a personal obligation: she must bury her brother Polyneikes against the law of Creon, who represents the state. In Sophocles' play it is Antigone's stubbornness transmitted into action

1 Cf. also: Simone Fraisse, Le mythe d'Antigone (Paris: A. Colin, 1974); Cesare Molinari, Storia di Antigone da Sofocle al Living theatre: un mito nel teatro occidentale (Bari: De Donato, 1977); George Steiner, Antigones (Oxford: Clarendon Press, 1984); Elisabeth Frenzel, Stoffe der Weltliteratur: Ein Lexikon Dichtungsgeschichtlicher Längsschnitte, 5. Aufl. (Stuttgart: Kröner, 1976); Herbert Hunger, Lexikon der griechischen und römischen Mythologie: Mit Hinweisen auf das Fortwirken antiker Stoffe und Motive ... bis zur Gegenwart (Vienna: Hollinek, 1953).

2 Antigone was the last of the three Theban plays - chronologically it was the first one. The play departs significantly from the Theban legend (as presented in Aeschylus' Seven against Thebes). 
that shows her love for her family. Antigone's suicide also destroys Creon's family, so the play ends with tragedy for both parts. ${ }^{3}$

The problem of Antigone always returned in the tragic period of human existence: when the values of humanity were rejected and when the rights of the human being were not respected. We have some plays from the twentieth century that were influenced by Antigone's motif. During the World War I, the German author Walter Hasenclever wrote his Antigone (1918). ${ }^{4}$ During the World War II, the French existentialist author Jean Anouilh wrote Antigone, ${ }^{5}$ a play that provoked conflicted reactions of the politicians. ${ }^{6}$ Antigone was adapted into a modern form. This play also had a particular fate in the socialist "Eastern" cultures: it was very quickly translated and rapidly staged. The play and its performances influenced the cultural atmosphere in the Czech Republic and Slovenia significantly. (Slovene playwright Dominik Smole wrote his Antigone under the influence of Anouilh).

After World War II, German playwright Bertolt Brecht published his Antigone under the title Antigone Modell; ${ }^{7}$ it was based on the translation by Friedrich Hölderlin. His focus was on the crisis of war. ${ }^{8}$ All three plays made a deep impression on audiences.

We will analyse here a selection of contemporary West and South Slavic dramas (nine) that were inspired by Antigone's myth, with an emphasis on the 1950 s and 1960s; we will also explore the complicated question of the growth of mythological drama in East Europe after World War II, ${ }^{9}$ using a comparative methodological approach focused on vibrant models of the intertextual dialogue.

At the end of the fifties and the beginning of the sixties, in all three main cultures of Yugoslavia, the wave of mythological dramas was launched by the

3 The translation of the play was also very important for Slavic national literatures and cultures: in the 2oth century Sophocles' play was staged five times in the National Theatre (Národní divadlo) in Prague.

4 Walter Hasenclever, Antigone, Tragödie in 5 Akten, 2. Aufl. (Berlin: Paul Cassirer, 1918).

5 Jean Anouilh, Nouvelles pièces noires: Jézabel, Antigone, Roméo et Jeannette, Médée, ed. pr. 1946 (Paris: La Table ronde, 1957).

6 For the first time it was performed in the Atelier theatre in Paris in 1944 under the German occupation.

7 The story of two sisters confronted with the body of their dead brother is situated in Berlin in 1945 .

8 It was published under the title Antigone, based on Sophocles' translation by Hölderlin and adapted for theatre by Brecht. It was performed for the first time in Chur Stadttheater in Switzerland in 1948.

9 Cf. also Alenka Jensterle-Doležal, “Antigona v povojni slovanski dramatiki, mit ali politična alegorija?” Opera Slavica 6.3 (1996) 20-28; “Mit o Antigoni: metafora ali alegorija; Južnoslovanska dramatika po drugi svetovni vojni" in Halina Mieckowska and Julian Kornhauser, Studia slawistyczne (Kraków: Universitas, 1998), 153-161; "Mit Antygony w dramacie słowiańskim” in Wielkie tematy kultury w literaturach słowiańskich, ed. by Anna Paszkiewicz and Łucja KusiakSkotnicka, Slavica Wratislaviensia 122 (Wrocław: Wydawnictwo Uniwersytetu Wrocławskiego, 2003), 249-256; Mit o Antigoni v zahodno- in južnoslovanskih dramatikah sredi 2o. stoletja (Ljubljana: Slovenska matica, 2004), 263. 
most famous playwright fascinated by ancient motifs: ${ }^{10}$ a Serb, Jovan Hristić, a Croat, Marijan Matković, and the Slovene Dominik Smole. ${ }^{11}$ At the same time, another Croat author, Drago Ivanišević, wrote a psychological drama Ljubav $u$ koroti (Love in Mourning, published in 1955, staged in 1957) based on the motif of Antigone. The plot is based on a love triangle among two sisters, Marta and Marija, and Ognjen, who is Marta's ex-suitor and Marija's current fiancé. The conflict is rooted in the past: Marta is a staunch communist and has a very pragmatic personality; because of her political beliefs she betrayed her brother during the war and Ognjen, her lover, executed him. She feels guilty about that and is mourning her brother. Marija, on the contrary, is presented as a decadent sensualist. A resolution to the psychological conflict and also the moral problem proves impossible.

The Serbian playwright Oto Bihajli-Merin was writing a play, Nevidlivi kapija (The Invisible Gate), for three years (from 1953 to 1956) and published it in $1957 .{ }^{12}$ He depicts the period of World War II in Croatian society and the complex development of the socialist society divided between different political ideas after the war. Antigone's father died in the conflict and Antigone was mourning him during the war and also after it - even though the communist party and her lover Ljubo forbade her from expressing her emotions because her father was on the wrong political side. The realistic presentation of characters and the action turn rapidly into an absurd picture. Here also we observe the dualistic world of romantics and idealists on one side and realists and sensual hedonists (represented by Ismene) on the other. In Serbian culture, Jovan Hristic continued with the series of mythological dramas, using allegory and apocrypha in an artistically perfect form. ${ }^{13}$

Slovene author Dominik Smole wrote Antigona in 1959, and in 1960 produced it on an alternative stage called Oder 57. In the play he used Sophocles' plot: he follows the main action (the heroine must bury the dead brother), but his ancient world gets modern characteristics. Antigone is not presented on stage, but all the others speak about her actions - she becomes the moral imperative for all the others. The most tragic hero in the play is Kreon: as a ruler, he loses his identity and his humanity, and becomes just a merciless king. The conflict is presented as a struggle between the claims of the conformist little bourgeois world and the power of Antigone's belief in the spiritual world of

10 Marijan Majetić, "Antička drama na zagrebačkih pozornicah" in Rad Jugoslovenske Akademije znanosti i umijetnosti 5 (1962): 519-533; "Antičke teme u novijoj hrvatskoj drami (1860-1961)," Književnik 3.1.23 (1961): 557-569.

11 Some of the Yugoslav critics wrote about a mode of using ancient myths in drama. (Cf. Jože Koruza, "Vprašanje mita kot mode in 'zaščitnega paravana," Primerjalna književnost 1 (1981): 24-28).

12 Oto Bihajli-Merin, Serbian critic and literary scholar, tried to explain the origins of his play in the essay: "Putovi do moje Antigone," Književnost 22.3 (1956): 203-217.

13 In his essay he proclaimed his desire to discover the historical validity of the myth - metaphor. Jovan Hristić, “Antički mit i savremena drama,” Izraz 5.10.11/12, (1961): 116-128. 
ideas and ideals. The characters are "stuck" in existentialist situations. ${ }^{14}$ The poetical drama is written in the metaphorical style. The performance was considered an event in the whole of Yugoslav theatre of the time.

Ancient myths and particularly the character of Antigone have long occupied a special place in Polish literature. ${ }^{15}$ The Polish author Artur Marya Swinarski wrote the play Godzina Antygony (Antigone's Hour) between years 1948-1949 but published it in 1960 in Paris. He depicts the war in Aragonia in the fall of 1937, where soldiers from various nations fought in the Spanish revolution. It is a pacifist drama using Antigone's theme of a burial refused to a fallen soldier.

Another Polish playwright, Krystyna Berwińska, wrote Ocalenie Antygony [The Saving of Antigone] in 1948 and published it in 1954. In the first act, Antigone wants to bury her dead brother, and in the second, her life is threatened by the revolutionary crowd. The playwright exposes the dark side of the revolution. Still another Polish playwright, Nora Szczepańska, dedicated the first act of her play Kucharki (The Cooks, 1960) to the story of Antigone. ${ }^{16}$ The ancient plot cannot be reproduced from the myth any more: Mała buried the dead body before Antigone came; tragedy has no place in the banal, modern world. Between the years 1958-1959, Roman Brandstaetter, another Polish dramatist, wrote the play Cisza (Silence, published in 1961) as the last part of his mythological tryptic. Because of its predominantly literary character the play was never staged. The dramatic plot is a variation of the old Greek myth. Antigone is an absurd heroine: at first, she is convinced that her action is nonsensical. The chorus persuades her to change her mind. In the second act, she prepares for her death. Death is depicted as a positive category in that world.

In 1962, in Slovakia, Peter Karvaš wrote another variation of Antigone: Antigona a tí druhy (Antigone and the Others). The action is presented in a World War II concentration camp. The emphasis in the play is on Antigone's action: in the world of prisoners the dead comrade Polly must be buried, and the act of the burial is a moral and political obligation for all. The whole presentation has a black and white perspective to it: on one side of P. Karvaš world there are the evil Germans, on the other political (communist) and other prisoners who are trapped in the hopeless environment of the concentration camps.

Czech authors also used the myth of Antigone some years after the war. ${ }^{17}$

\footnotetext{
Cf. Marjeta Vasič, Eksistencializem in literatura (Ljubljana: Državna založba, 1984), 11 -120. Cf. "Z dziejów Antygony w Polsce" in Jerzy Starnawski, Maria Wichowa, Andrzej Obrębski, Antyk w Polsce (Łódź: Wydawnictwo Uniwersytetu Łódzkiego, 1992), 24-40. Cf. also Elżbieta Olechowska's article Ancient Plays on Stage in the Communist Poland in the present volume.

The other two plays were about Hamlet and Godot.

Cf. the collective publication Antika a česká kultura (Prague: Academia, 1978); Eva Stehlíková, Classical Themes in Czech Drama, Československa akademie věd, Listy filologické 1 (1968): 91; Adam Závodský, "Tschechische Dramen auf Antike Motive" in Antiquitas Graeco-Romana ac tempora nostra, ed. by Jan Burian and Ladislav Vidman (Prague: Academia, 1968), 553-558.
} 
In 1967 Czech playwright Milan Uhde, influenced by the literary and philosophical movement of the absurd, wrote the play Děvka z města Théby (The Whore from the City of Thebes). The play is a pessimistic vision of the modern world before the end of the civilisation. In the conflict, the degenerated, morally corrupt society of an imaginary town of Thebes dominates. It is not possible that an individual changes society; the existence of Antigone the heroine is absurd. She also cannot be saved; the city destroys her morality and idealism. ${ }^{18}$

It was not for the first time in literature that there existed a fashion or trend about how ancient Greek mythology was brought into life and how the playwrights incorporated it in various texts. We know from literary history the importance of the myth of Prometheus for the literature of the romantics. The myth of Orpheus also had its peculiar fate in the texts of fin de siècle literature. Orestes was essential for existentialism - also because of the famous play by J.-P. Sartre. To highlight the absurd position of modern man, the existentialist Albert Camus focused on the myth of Sisyphus (published in 1942, Le Mythe de Sisyphe).

Playwrights in the West- and South Slavic literatures after World War II, living under the pressure of socialist ideology, liked to incorporate the myth of Antigone in their plays: it occupied a particular place in respective national cultures. The variations and transpositions of the myth reflected different aspects of societies and their problems and mirrored complicated relations between the dramas, their performances, theatres, and culture. The audience could sense the complicated relations between the theatre and society: the playwrights suggested in the plays what was happening in post-war "Eastern" societies. The myth of Antigone was, in the second generation of Slavic dramatists, one of the most frequently used and performed in this area. It is not a coincidence: this myth suggested to the readers and viewers the possibility of political interpretation of the dramatic conflict, which existed already in Sophocles' version. G. W. Friedrich Hegel understood the conflict between Creon - representing the claim of the state (the law of Zeus) - and Antigone, who represented the claim of the family (reflecting the love between family members and also the law of the underworld gods). ${ }^{19}$ He named two typical ancient Greek tragedies: Oedipus and Antigone. He emphasised the moral

18 In the same time as Slavic playwrights exploited the myth in literature, some plays with the myth of Antigone appeared elsewhere in the world. The Haitian writer and playwright Félix Morisseau-Leroy translated and adapted Antigone into Haitian Creole under the title Antigon (1953), rethinking through the performance their religious experience of Vodou. In 1967 Spanish playwright María Zambrano wrote La tumba de Antigona, Antigone's tomb. In 1968 Puerto Rican playwright Luis Rafael Sánchez published La Pasión según Antígona Peréz, setting the conflict in the contemporary world. In 1977 Antigone was translated into Papiamento in Aruba by the director of the play Ms. Burny Every together with Pedro Velázquez and Ramon Todd Dandaré.

19 Cf. Georg Wilhelm Friedrich Hegel, Aesthetik I, 219-309, Aesthetik II, 479-581 (Leipzig, 18201829); Religonsphilosophie II, 96-156 (Leipzig 1928). 
dilemma; for him, the suffering of the tragic hero is a means to reconcile opposing moral claims, which are both justified. The heroes - including Antigone - believe in one ethical system and because of that come in conflict with the ethical claims of another. The two claims represent what Hegel regards as essential the ethical claims: Antigone's problem is a question of conscience.

We could find political subtexts and codes almost in every adaptation of the discussed play. On the other hand, the story has its metaphysical dimensions, which could lead to symbolic interpretations of the myth - appropriate to these tremendous historic and social changes.

The second generation of the Slavic playwrights returned to antiquity and myths. Contrary to the first generation, they began to discover their individual style of writing. In their texts we can find all the tendencies of modern drama of the twentieth century, occurring in the Slavic drama of the sixties: ${ }^{20}$ the disappearance of the protagonist, a fragmented view of time and place (which meant the fragmentation of the motifs and themes), and, above all, the disappearance of a unique central conflict and dramatic plot. In these plays there is usually no rigorous dramatic plot any more: the playwrights in some way disregard the fundamental need for plot and unity, and also for the consistency of characters. The theatrical language becomes significant in connection with the possible performance and poetics of theatre space. The playwrights also think about the rhetoric of dialogues and the possibility to utilise all the theatrical means of expression.

The plays of "Slavic" Antigone were created in the shadows of the horrifying events of World War II and after it. In the play Ocalenie Antygony by K. Berwińska, the descriptions of the imaginary Thebes in a state of war represent extreme images of society under the law of historic change: the plot is grotesque, with allusions to the Polish war situation. The play by A. M. Swinarski takes place in the divided society in revolutionary pre-war Spain. The conflicts in the plays of D. Ivanišević and O. Bihajli Merin are rooted in World War II Yugoslavia. The Slovak P. Karvaš, in the play Antigona a tí jiní, was one of the first playwrights to depict the desperate and hopeless atmosphere of concentration camps. The dilemma of Antigone of the Slovene author D. Smole (the play was of importance not only to Slovene culture but also to all of Yugoslavia) is the tragedy of brothers deprived of burial: the 10,000 sacrificed victims - the Slovene home guards, the territorial army, killed by the partisans after the war. These were the unacknowledged victims about whom nobody was allowed to speak under the new regime. The playwright focused on the "silenced" history, on the problem of the reinterpretation of history by the victors.

Some Slavic dramatists used the ancient myth as a vehicle to present difficult social problems, to underline political traumas, and also to promote

20 Irena Slawinska, Wspólczesna refleksja o teatrze (Kraków: Wydawnictwo Literackie, 1979). 
actual philosophical ideas; in interpreting the myth they used "Aesopian language." In 1961 Martin Esslin defined this idiom (already used before by György Lukács) ${ }^{21}$ as the language to express the function of the absurd in the socialist states. When he spoke about the spread of the theatre of the Absurd in Eastern Europe, he highlighted the hidden meaning of a political conspiracy for the socialist audience as one of the reasons for its success in the Eastern European cultures:

"It is one of the ironies of the cultural history of our time that, after the thaw had set in Eastern Europe, it was precisely the theatre of Ionesco that provided the model for an extremely vigorous and barbed kind of political theatre in some of the countries concerned." 22

The analysis of the myth of Antigone in these plays could only be confirmed and understood by examining the social and historical context of that time. The different versions of the myth of the brave female hero and her action, express the social and political significance of the unburied victims of World War II and immediately after that. The motif of the burial of the body of a brother could become timely in the atmosphere of general awareness of supressed traumas and neglect of ethics and values in the socialist societies. This is a theme for a society with the history of frustration with such abandoned dead: history in new socialist states was changed and ideologically adapted to the needs of the new system and its rulers. It was possible to speak only about the "ideologically acceptable dead": the ones who died fighting on the right side but not about the others. For more than forty years it was forbidden to speak about those 'others'. The oppressive grip of the socialist government extended beyond death. It changed only in the 1990s, when people became able to give a symbolic burial to their killed relatives. The interpretation of Antigone allowed for the recognition of truth and catharsis, if only in "the field of imagination".

In these plays Antigone and Creon merge into one character; in their tragic action both oscillate between family values and the state claims and pressures: between their obligations and their feelings, between love and responsibility to the state and society, between the personal and the public sphere. It was a typical trauma for the intellectuals in Eastern Europe after World War II.

In Central-European plays of that period there was a profound change in the presentation of the two central characters: Antigone and Creon. The brave Antigone with her unconditional action, her life bound to her fatal destiny of death, sealed by cruel fate, is the point of orientation in this myth. The original, strong individuality of Antigone in her modern variations loses her power and her raison d'être; her voice disappears among the voices of others. In these dramas she approaches Creon's characteristics; their personalities become similar.

21 And by others, cf. the Introduction to the present volume.

22 Martin Esslin, The Theatre of the Absurd (London: Penguin, 1970). 
Her actions lose their sense and moral power; Antigone does not want to bury Polyneikes anymore. Already in the play of K. Berwińska, Antigone abandons the right to bury her brother. In the play of N. Szczepańska Antigone arrives too late to act, as Mała has already buried the body. In the beginning of Brandstaetter's play Antigone does not want to accept her mythical role, because she is convinced of the absurdity of all women's actions: the chorus of girls persuades her to do just the opposite. In the drama of D. Ivanišević, the action of burying has been already accomplished in the past, and, because of that, Antigone remains psychologically unstable and torn to pieces all her life. Antigone in the play of P. Karvaš is not successful in burying the remains because the soil is frozen and too hard to dig. In the play of $\mathrm{D}$. Smole the reality of action is questioned: Antigone is looking for the body throughout the play, but she does so somewhere in the distance, not on stage; we receive mere reports of her attempts. At the end of the play we do not know if she was successful: we could assume that perhaps the page boy took away the reality of her action.

In these Slavic dramas the importance of the character of Creon significantly grows. In the sixties the critics and the philosophers prefered him to Antigone: in 1967 the Czech philosopher Jan Patočka proclaimed Creon the hero of our time. ${ }^{23}$ In 1959 the French philosopher Jacques Lacan, in his study Ethics of Psychoanalysis, suggested that the perspectives of communism do not in any sense differ from the mental horizons of Creon, the leader and head of a communist state; if we were to predict the future, we would say that his functional pragmatism would conquer the whole world. ${ }^{24}$

In the analysed plays Creon sometimes functioned as a symbol for the communist leader, the absolute dictator of the socialist government of the typically bureaucratic state. However, Antigone, too, begins to look like Creon: their figures mingle into one another. Creon in the analysed dramas also has the problem with his role as the antagonist and the opposition to Antigone's idealism. Already in the play of Sophocles the drama of Antigone is also the drama of Creon, and we could also say the same for the later plays inspired by that myth. In the analysed dramas, his role becomes more powerful, and in the political interpretations, Creon becomes a real dictator, which allows no compromise. In the plays of D. Smole and M. Uhde, Creon's humanity is accentuated and his personality underlined, his moral convictions are close to those of Antigone. Creon is morally split between the man and the politician/ bureaucrat, between his feelings and his obligations as a ruler.

The scholars also highlighted the philosophical roots of this myth. The German critic Margaret Dietrich discussed in 1961 the myth of Antigone within the circle of the Labdacids, with the myth of Orestes as part of the

23 Jan Patočka, “Ještě jedna Antigona a Antigone ještě jednou”, Divadlo 18 (1967), 1-6.

24 Jacques Lacan, Lecture, I. Hribar, trans. Nova revija 51/ 52, Ljubljana 1986, 1999. In English: J. Lacan, The Seminar of Jacques Lacan VII: The Etics of Psychoanalysis, translated by Dennis Porter (New York: W.W. Norton, 1992), 240-286. 
existentialist cycle of myths. ${ }^{25}$ On the contrary, the Polish critic Jan Kott proclaimed that this myth represents a typical example of a reductio ad absurd$u m .{ }^{26}$ The interpretations of the myth also reflected different ideologies and philosophical movements. In Slovenia the reception of Sophocles' and Smole's Antigone reflected the different philosophical movements of the sixties: from existentialists and the absurd movement to interpretations following the philosophy of Heidegger $;{ }^{27}$ later reception also exhibits the ideas of Lacan's psychoanalysis, which was very well received by Slovene intellectuals.

In the Central European cultures of that time the existentialist movement enjoyed a powerful influence, still present in the fifties and sixties. Existentialism according to Sartre considers that existence precedes essence; each individual - not a society and a religion - is solely responsible for giving meaning to life, for their actions: people are defined based on how they act. The individuals must fight against the meaningless world that surrounds them - and that is also the meaning of Antigone' behaviour, seen from a modern point of view. Particularly in the dramatic worlds of D. Smole and R. Brandstaetter all characters must decide whether to bury or not to bury Polyneikes' corpse. In the drama of D. Smole, we find in the peaks of action the fatal moments of existentialist decision, which tear the characters to pieces.

In the 1950 s the theatre of the absurd spread throughout Europe: there were several productions of plays by Eugene Ionesco and Samuel Beckett, in the sixties the plays by Edward Albee. The absurd authors describe lonely men in a desolate world. In the play of M. Uhde, the behaviour of Antigone loses its raison dêtre. In the end, the sensual and degenerated city of Thebes overcame her character, her idealism and her deep motivation.

All analysed plays reflected the classical conflict between moral obligations of the individual and the pressure of the collective. The reward for Antigone's brave act is her death. She became a martyr for society's future well-being and the moral balance: in this sense, she traded her life for bringing moral values back to the world. An individual such as Antigone in these plays has a hard task and difficult goals: she must find sense in her life and her actions and discover her identity between her personal space and the public sphere. The modern Antigone tries to solve the dilemma of her individuality, but the power of her action is dwindling.

On the other hand, in all these plays the role of the collective is strengthened. The picture of the collective force - of society - acquires grotesque characteristics. The city functions as a mirror and an allegory of the whole of society. The historical dimension also brings invigoration. A picture of

25 Margaret Dietrich, Das moderne Drama: Stromungen, Gestalten, Motive. 3 ed. (Stuttgart: A. Kröner, 1974), 394.

26 Jan Kott, Zjadanie bogów, szkice o tragedii greckiej (Krakow: Wydawnictwo Literackie, 1986).

27 The Czech philosopher Jan Patočka in his interpretation of Sophocles' Antigone also derived his ideas from Heidegger (Patočka, op. cit.). 
the collective is depicted in bloody, rebellious society in the drama of $\mathrm{K}$. Berwińska, or in the pragmatic, one dimensional and also depressive Thebes of D. Smole. The darkest presentation of the collective model of a society full of suffering is the city of Thebes of M. Uhde, which is sinking in the mire of evil deeds and moral decadence. Antigone loses her force to finish her act of burying the dead body. Even though Creon is on the other side as her enemy, he is also threatened by the citizens of Thebes: in his reactions and deeds he is becoming similar to her. Also, the other characters have minimal possibilities to react and change things, to rebel against the political and social system of Thebes. Antigone in the drama of K. Berwińska is afraid of the demoralised crowd. The people of Thebes conquer, Antigone's solution is not possible anymore, and the crowd persuades her to commit suicide. From that point of view we can see the changing perspective of the dramatist: the first part of the play represents the new variations of the myth and also the drama of the individual, while the second one depicts the drama of the revolution and the conflicted society. Also in the play Kucharki of N. Szczepańska the collective of the cooks conquers the situation; they represent the continuation in the world. In the play of A. M. Swinarski, only the collective exists, and, inside the collective, we can recognise just the particular types of people: the soldiers, the actress, etc. The act of burying is a collective action. First the soldiers experience that act, later two religious sisters - fanatics. The problem of belonging to society is the central conflict in the play of D. Ivanišević. Marta is simultaneously Antigone and Creon because she must also decide between two possibilities: either to become a member of the revolutionary party or to show feelings for the dead brother. The conflict between the rational and emotional side of the individual presented ideologically is not solved till the end of the play.

The act of burial becomes a collective act, and it transmits from one person to the other. Not only Antigone but also the other people try to finish the heroic act. In the drama of P. Karvaš the specific people are not so significant; even the little dancer Anti loses her importance. This is because in the ideological view the heroic act of burying is transmitted from one person to another in the group of prisoners in the concentration camp. The dissonance between the individual and the society in the Antigona of D. Smole is hugely disproportionate. Creon is the state leader, who installs the order at any price. The imaginary collective raises for all the imperative of burying the enemy brother. Even though all are impressed by Antigone's moral decision, only Anti and the page boy make a stand against them. The act of burial is presented more as a symbolic act than concrete action. Also tragically depicted is the conflict between the individual and the collective in the play of M. Uhde. Antigone - as Creon in the past - is the carrier of ideals; she wants to change the world. In the end, the city of Thebes and its pragmatic philosophy conquers her.

When we analyse the function of the myth in these plays, we find a change in appearance: it is possible to recognise the line between the political 
plays with allegorical plots from the fifties and the metaphorical plays from the sixties when ancient motifs become metaphors of modern subjectivity. The Serbian dramatist Jovan Hristić, the author of the Serbian mythological plays of that period, maintained in 1962 that neither Oedipus, Orestes, nor Penelope were real persons, but were just metaphors representing historical values. ${ }^{28}$ Polish literary critics wrote about similar tendencies in the Polish mythological drama. ${ }^{29}$

The mythological texts link political allegory with the concretised metaphor of the postwar normality of the East European countries: they oscillate from historical presentation to poetic expression, in which symbolic themes are the metaphors for philosophical thoughts. According to the tendencies of modern drama there are no coherent plots anymore and more or less only the fragments of the ancient story exist. If the mythological narrative is an allegory for the political situation, it represents the problem of losing identity in the modern, collective world, where the old "Cartesian subject" lives under the pressure of the political structure. Antigone in this society also becomes a cultural phenomenon, an archetype for an ethical ideal and a cultural model for a social outsider.

At the beginning of the wave of mythological dramas there was a tendency to write political plays in which the dramatist allegorically presented the political frustration of the society. In the later dramas inspired by Antigone the allusions to political reality were not so clear and not so common. Later in the sixties the authors of mythological drama liked to cultivate metaphor with more general meaning and symbolic, individualistic poetics. The openness of the style and the poetical theatre's proximity to the philosophical meanings are typical for Cisza by R. Brandstaetter, Antigona by D. Smole, and Antygona by M. Uhde.

The myth of Antigone is still prevalent at the end of the twentieth century. In this time of violence and wars, in this period of manipulation and historical traumas, in this time of postmodernism and new political and historical changes, the myth of Antigone is still a measure for the development of society and a measure for the state of awareness of its civilisation. Still, the question remains as to where the borders of the Creon's rational pragmatism and his loyalty to the state and society end, and when Antigone's true love and affection for her nearest relatives begins. Her respect for the dead and her search for the sacred ideas and humanism in what is eternal.

The myth of Antigone in these societies had great importance also for the development of theatre and the evolution of the theatrical world. The myth unveiled the significant connection between the meaning of the myth and its historical interpretations. It represented the changes in culture after World

28 Jovan Hristić, “Antički mit i savremena drama,” Izraz 5.10.11.12 (1962): 116-128.

29 Elżbieta Wysińska, “Drogi przez antyk ciąg dalszy,” Dialog 11 (1962): 121-121; Cezary Rowiński, "Moda na mity greckie," Dialog 9 (1962): 116-128. 
War II, and it depicted new experiences in drama and new literary ideas. It also reflected the development of philosophical thinking and critical approaches.

As we have seen, the transpositions of Antigone have their unique life also in the cultural, not just in the literary life of nations. The myth of Antigone is unexpectedly relevant in the contemporary world and that we can see from the new plays inspired by this myth, which appeared in Slavic drama in the seventies, eighties, and nineties. Playwrights in the historically exposed situations wrote new plays about Antigone, which affirmed a renewal of the old images again. ${ }^{30}$

\author{
Alenka Jensterle-Doležal \\ Charles University, Prague \\ Alenka.Dolezalova@ff.cuni.cz
}

\title{
BIBLIOGRAPHY
}

Anouilh, Jean. Nouvelles pièces noires: Jézabel, Antigone, Roméo et Jeannette, Médée.

Paris: La Table ronde, 1957; 1st ed. 1946.

Bihajli-Merin, Oto. "Putovi do moje Antigone." Književnost 22.3 (1956): 203-217.

Dietrich, Margaret. Das moderne Drama: Stromungen, Gestalten, Motive. 3rd ed.

Stuttgart: A. Kröner, 1974.

Esslin, Martin. The Theatre of the Absurd. London: Penguin, 1970.

Fraisse, Simone. Le mythe d'Antigone. Paris: A. Colin, 1974.

Frenzel, Elisabeth. Stoffe der Weltliteratur: Ein Lexikon Dichtungsgeschichtlicher

Längsschnitte, 5th ed. Stuttgart: Kröner, 1976.

Hasenclever, Walter. Antigone, Tragödie in 5 Akten, 2nd ed. Berlin: Paul Cassirer, 1918.

Hegel, Georg Wilhelm Friedrich. Religonsphilosophie 2 (Leipzig 1928).

- - - Aesthetik 1-2 (Leipzig, 1820-1829).

Hristić, Jovan. "Antički mit i savremena drama." Izraz 5.10.11.12 (1962): 116-128.

Hunger, Herbert. Lexikon der griechischen und römischen Mythologie: Mit Hinweisen auf das Fortwirken antiker Stoffe und Motive ... bis zur Gegenwart. Vienna: Hollinek, 1953.

Jensterle-Doležal, Alenka. "Antigona v povojni slovanski dramatiki, mit ali politična alegorija?” Opera Slavica 6.3 (1996): 20-28.

- - - "Mit Antygony w dramacie słowiańskim." In Wielkie tematy kultury w literaturach słowiańskich, ed. by Anna Paszkiewicz and Łucja Kusiak-Skotnicka, 249-256. Slavica Wratislaviensia 122. Wrocław: Wydawnictwo Uniwersytetu Wrocławskiego, 2003.

30 In 1972, Czech dramatist Vojtěch Trapl wrote a new Antigone - a version of Sophocles (Ananke). In 1976 Polish author Helmut Kajzar also wrote his paraphrase of Sophocles' play (Antygona) - staged in 1971, published in Nowy Wyraz in 1972; for more information about Kajzar, cf. Olechowska's article in this volume. In 1984, Miro Gavran, a Croat author, published another Antigone: Kreontova Antigona (The Creon's Antigone). In 1989, the Czech playwright Přemysl Roth wrote Polygone. In 1996, Slovene dramatist Dušan Jovanovič wrote a new Antigone (staged in 1996, published 1997) about the Balkan war. In 1992 Polish author Janusz Głowacki published Antygona w Nowym Yorku, dealing with the problems of the homeless and immigrants in the American society. 
"Mit o Antigoni: metafora ali alegorija; Južnoslovanska dramatika po drugi svetovni vojni." In Studia slawistyczne, ed. by Halina Mieckowska and Julian Kornhauser, 153-161. Kraków: Universitas, 1998.

-_- Mit o Antigoni v zahodno- in južnoslovanskih dramatikah sredi 20. stoletja. Ljubljana: Slovenska matica, 2004.

Koruza, Jože. "Vprašanje mita kot mode in 'zaščitnega paravana'." Primerjalna književnost 1 (1981): 24-28.

Kott, Jan. Zjadanie bogów, szkice o tragedii greckiej. Krakow: Wydawnictwo Literackie, 1986.

Lacan, Jacques. Lecture. Transl. by I. Hribar, Nova revija 51-52, Ljubljana 1986, 1999. In English: The Seminar of Jacques Lacan VII: The Etics of Psychoanalysis, translated by Dennis Porter. New York: W.W. Norton, 1992.

Ladislav Varcletal, ed. Antika a česká kultura. Prague: Academia, 1978.

Majetić, Marijan. "Antička drama na zagrebačkih pozornicah." Rad Jugoslovenske Akademije znanosti i umijetnosti 5 (1962): 519-533.

———. "Antičke teme u novijoj hrvatskoj drami (1860-1961)." Književnik 3.1.23 (1961): 557-569.

Molinari, Cesare. Storia di Antigone da Sofocle al Living theatre: un mito nel teatro occidentale. Bari: De Donato, 1977.

Patočka, Jan. "Ještě jedna Antigona a Antigone ještě jednou." Divadlo 18 (1967): 1-6.

Rowiński, Cezary. "Moda na mity greckie." Dialog 9 (1962): 116-128.

Slawinska, Irena. Wspólczesna refleksja o teatrze. Kraków: Wydawnictwo Literackie, 1979.

Starnawski, Jerzy. "Z dziejów Antygony w Polsce." In Antyk w Polsce, ed. by Jerzy Starnawski, Maria Wichowa and Andrzej Obrębski, 24-40. Łódź: Wydawnictwo Uniwersytetu Łódzkiego, 1992.

Stehlíková, Eva. “Classical Themes in Czech Drama." Listy filologické 1 (1968): 49-54.

Steiner, George. Antigones. Oxford: Clarendon Press, 1984.

Vasič, Marjeta. Eksistencializem in literatura. Ljubljana: Državna založba, 1984.

Wysińska, Elżbieta. “Drogi przez antyk ciąg dalszy.” Dialog 11 (1962): 121-130.

Závodský, Adam. "Tschechische Dramen auf Antike Motive." In Antiquitas GraecoRomana ac tempora nostra, ed. by Jan Burian and Ladislav Vidman, 553-558. Prague: Academia, 1968. 


\section{SUMMARY}

In the Realm of Politics, Nonsense, and the Absurd: The Myth of Antigone in West and South Slavic Drama in the Mid-Twentieth Century

The myth of Antigone remained relevant in the twentieth century, and new plays inspired by this myth appeared not only in the West but also in Slavonic drama during and after WW2. Oppressed societies, abuses of power, persecution and execution of political and ideological opponents create a fertile ground for a creative return to the Sophoclean tragedy. Some of the new plays have roots in the trauma of $\mathrm{WW}_{2}$, others in post-war Soviet domination. Significantly, these plays attach growing importance to the character of Creon. Among the discussed playwrights are two Serbs, Jovan Hristić and Oto BihajliMerin, two Croats, Marijan Matković and Drago Ivanišević, and the Slovene, Dominik Smole; four Poles, Artur Marya Swinarski, Krystyna Berwińska, Nora Szczepańska, and Roman Brandstaetter; one Slovak, Peter Karvaš, and one Czech, Milan Uhde.

\section{POVZETEK}

Področje politike, nonsensa in absurd: mit o Antigoni v zahodno- in južnoslovanski dramatiki sredi dvajsetega stoletja

Mit o Antigoni je v dvajsetem stoletju ohranil svoj pomen in nove drame, ki jih je navdihnil, se niso pojavljale samo na Zahodu, temveč tudi v slovanski dramatiki med drugo svetovno vojno in po njej. Družbena represija, oblastna zloraba, preganjanje in pobijanje političnih in ideoloških nasprotnikov - vse to je ustvarilo plodna tla za ustvarjalno vrnitev Sofoklove tragedije. Korenine nekaterih od teh novih dram so segle v travmo druge svetovne vojne, korenine drugih v povojno sovjetsko dominacijo. Pomenljivo je, da v teh dramah vse večji pomen dobiva lik Kreonta. Med obravnavanimi dramatiki sta dva Srba, Jovan Hristić in Oto Bihajli-Merin, dva Hrvata, Marijan Matković in Drago Ivanišević, ter Slovenec Dominik Smole; štirje Poljaki, Artur Marya Swinarski, Krystyna Berwińska, Nora Szczepańska in Roman Brandstaetter; ter po en Slovak, Peter Karvaš, in en Čeh, Milan Uhde. 